\title{
Design and analysis of bi-objective flexible job shop scheduling problem: A case study in construction equipment manufacturing industry
}

\section{İki amaçlı esnek atölye tipi çizelgeleme probleminin tasarımı ve analizi: İnşaat ekipmanları imalatı sektöründe bir vaka çalışması}

\author{
Hamdi Giray RESSAT ${ }^{*}$ iD \\ ${ }_{1}^{1}$ Department of Industrial Engineering, Engineering Faculty, Izmir University of Economics, İzmir, Turkey. \\ giray.resat@ieu.edu.tr
}

Received/Geliș Tarihi: 15.11.2018, Accepted/Kabul Tarihi: 15.04.2019

doi: $10.5505 /$ pajes.2019.35033

* Corresponding author/Yazıșlan Yazar Research Article/Araștırma Makalesi

\begin{abstract}
This paper presents a design and development of mixed-integer linear optimization model for scheduling of flexible job-shop production problem under capacity constraints by using exact solution algorithm. Modelling approach is designed in order to introduce data analysis in real situations, minimize production time in production lines, reduce total production costs, and reveal important features of mathematical programming problem in detail. The main purpose of this study is to obtain faster and efficient Pareto solution sets for bi-objective problem by using $\epsilon$-constraint method. Generated Pareto frontier using real life data is shared with decision makers. The GAMS programming language is used during the solution phase of a mixed-integer linear optimization model for bi-objective problem and production efficiency of the company is increased around $16.6 \%$ in terms of production cost.
\end{abstract}

Keywords: Flexible job-shop scheduling, Mixed-Integer linear programming, Discrete optimization

\section{Introduction}

Considering global competition conditions and increased awareness to the environmental factors, companies begin to develop innovative and adaptive management and production mechanisms in their systems. Customer expectations play essential roles in this transformation stage and they are located at the core of production systems. Therefore, companies try to satisfy customers by adjusting their systems to shorten delivery lead times, decrease production costs as well as reduce environmental effects.

According to the report published by Turkish Quality Association [1], customer satisfaction in the automotive sector increased 6\% between 2006 and 2014, and firms with higher customer satisfaction levels increased their market shares in domestic and international markets. Another analysis published by Turkish Quality Association [1] indicates that customer satisfaction levels increased by $36 \%$ in service industries in last decade. However, there are many obstacles in the satisfaction of these targets due to high complexities of products, increased level of variations, integration of transportation systems, lack of inventory levels, etc. According to perspective of companies, customer losses due to delayed orders are very critical topic and required to be taken preventive actions immediately. This competitive environment pushes companies to offer special solutions for their customers to serve in shorter lead times. Therefore, production planning

\begin{abstract}
Öz
Bu çalışmada esnek atölye tipi üretim çizelgeleme probleminin kapasite kısıtları altında programlanması için karmaşık tamsayı doğrusal optimizasyon modelinin tasarlanması ve geliştirilmesi kesin çözüm algoritması kullanılarak sağlanmıștır. Modelleme yaklașımı, gerçek vakalar üzerinden veri analizini sağlamak, üretim hatlarındaki üretim süresini en aza indirmek, toplam üretim maliyetlerini azaltmak ve matematiksel programlama probleminin önemli özelliklerini detayl olarak ortaya koymak için tasarlanmıştır. Bu çalışmanın temel amacı, iki amaçlı çizelgeleme problemleri için $\epsilon$-kısıt yöntemini kullanarak daha hızlı ve verimli çözüm setleri elde etmektir. Gerçek hayat verileri kullanilarak elde edilen Pareto çözüm setleri karar vericiler ile paylaşılmıştır. Íki amaçlı çizelgeleme problemi için geliştirilen karmaşık tamsayı doğrusal optimizasyon modelinin çözüm așamasında GAMS programlama dili kullanılmıștır ve șirketin üretim maliyetlerinde \%16.6'lık bir iyileștirme gerçekleștirilmiștir.
\end{abstract}

Anahtar kelimeler: Esnek atölye tipi çizelgeleme, Karmașık doğrusal tamsayı programlama, Ayrık optimizasyon

and scheduling is getting more attention and become more critical topic for companies. According to the studies conducted in recent years, there are significant number of studies considering production planning and scheduling together. Initial study on scheduling emerged in 1950s by Johnson [2]. A single machine-scheduling problem in order to minimize maximum completion time is studied by Van Wassenhove and Baker [3]. Their main purpose is to get possible time/cost trade-offs for scheduling problems. Brucker and Schlie [4] introduces flexible job-shop concept and Yazdani et al. [5] contributes differences between classical and flexible job-shop planning problems. If production system works with minimum number of customized and unique orders, system turns out to be job-shop. Kacem et al. [6] introduces two new approaches to solve job-shop scheduling problems in the study; partial and full flexibility. These approaches are also applied for flexible job-shop scheduling problems. Each operation can be processed depending on the identical or non-identical machine characteristics in the partial flexible job-shop problems. On the other hand, all machines having same characteristics can be processed at the same time or different times in partial flexible job-shop problems. In full flexible job-shop problems, operations can be arbitrarily assigned to appropriate machines. Paulli [7] mentions scheduling problems to minimize total make-span for multi-machine production systems. According to Watanabe et al. [8], if production environment is complex and there are circulated flows in network, it is difficult to be 
solved with conventional optimization techniques for real-life cases. Therefore, some hybrid methods should be used in the solution of flexible job-shop scheduling problems. Some of these hybrid models can propose some feasible solution sets for combinatorial NP-hard problems.

Fattahi et al. [9] proposes mathematical model with two metaheuristic algorithms to solve flexible job-shop problems. Gao et al. [10] designs integrated approach by using hybrid genetic algorithm (hGA) for bi-objective problems to minimize total make-span and machine workload. Chiang and Lin [11] obtains solution sets by using evolutionary algorithms for bi-objective problems. Li et al. [12] introduces another algorithm called frog algorithm to address bi-objective problems. Abdeljaouad et al. [13] develops a custom solution algorithm to minimize the maximum completion time of planned jobs. Gedik et al. [14] presents a constraint programming optimization model with logic-based Benders decomposition algorithm that takes account of total profit maximization and reduction of machine setup times. Ozguven et al. [15] designs two different mathematical models to minimize production completion time and to balance workloads of machines, and shares solution sets for both models. Xue et al. [16] develops hierarchical production planning concept by integrating production preparation times, inventory costs, production costs, and seasonal demands between product types and components of the product families into the optimization model. This nonlinear mathematical model reduces the production costs by using linearization algorithms. Shen et al. [17] handles production scheduling problems by using two meta-intuitive algorithms based on Tabu Search algorithm. Gao et al. [18] presents a harmony search algorithm to get Pareto frontier for multi objective problems by considering make-span and number of tardy jobs.

The contributions of this study can be summarized as follows:

1. A mixed-integer linear optimization model for flexible job-shop scheduling problem is designed and developed,

2. Proposed bi-objective problem by considering minimization of make-span and total processing cost is analyzed by using real-life data,

3. Apart from the heuristics models, after applying some pre-processing and logic cuts, exact solution method with $\epsilon$-constraint method (AUGMECON) is used to collect feasible Pareto frontier for decision makers,

4. Different scenarios are compared with current status of the company and before/after analysis are made to highlight the important points of time consumption and cost in production systems,

5. Performance of the proposed model and solution methodology is tested on three different sets of benchmark instances.

This study is divided into six sections. After this introduction and literature review part, Section 2 presents problem definition of a real-life case and details of proposed mathematical model. In addition, this section provides detailed information about assumptions for the mathematical model in bi-objective scheduling problem. Section 3 includes some technical information for solution methodology of this problem. Section 4 includes the information about the initial data and some parameters that are used during the calculations. Section 5 gives results of real-life cases and comparative results for three scenarios are shared. Finally, Section 6 shows the general overview and some future steps of the problem.

\section{Problem description}

The principles and methods used in the study are explained in this section. The details of real-life problem and mixed-integer linear mathematical model are defined.

In this study, production planning complexity caused by highlevel customer satisfaction is considered. Companies sometimes cannot satisfy customer demands on time and this situation leads to customer dissatisfaction and even customer losses. This means that they may produce more or less than expected levels. Both situations cause either lost-sales or inventory costs for companies. In the proposed case studies, orders are assumed to be received from customers on weekly basis. According to these orders, necessary raw materials are requested from warehouse and transferred to the manufacturing area to form up products. These finished goods wait in the stock area to be shipped based on customer order arrivals. Finished products are usually delivered by using road transportation, especially heavy-trucks. This delivery process between warehouse of the company and customer zones occurs at the end of every week (on Saturdays).

\subsection{Mathematical model}

\subsubsection{Indices}

$\begin{array}{cllc}i \& i^{\prime} & : & \text { Tank types } & i \& i^{\prime}=1,2, \ldots, I \\ m & : & \text { Stations } & m=1,2, \ldots, M \\ k & : & \text { Order sequences } & k=1,2, \ldots, K\end{array}$

\subsubsection{Parameters}

$t_{i m}^{\text {Pro }} \quad$ : Processing time of product $i$ in station $m$.

$d_{i} \quad: \quad$ Demand for product $i$.

$\mathrm{Cap}_{m} \quad$ : Daily working capacity of station $m$.

$W D \quad: \quad$ Number of working days in week.

$t_{i i^{\prime} m}^{\text {Setup }}:$ Setup duration from product $i$ to product $i^{\prime}$ in

station $m$.

$c_{i m}^{\text {Pro }} \quad$ : Processing cost for product $i$ in station $m$.

$c_{i}^{\text {Lost }} \quad: \quad$ Lost sale cost for product $i$.

$c_{i i^{\prime} m}^{\text {Setup }}:$ Setup cost from product $i$ to product $i$ 'in station

$m$

$c_{i}^{I n v} \quad: \quad$ Inventory cost for product $i$

Due $_{i} \quad$ : Due date for product $i$.

\subsubsection{Decision variables}

\begin{tabular}{|c|c|}
\hline$H_{i}$ & Number of backorders for product $i$. \\
\hline $\operatorname{Inv} v_{i}$ & Inventory level of product $i$. \\
\hline$t_{\text {imk }}^{\text {Start }}$ & $\begin{array}{l}\text { Process start time for product } i \text { in position } k \text { in } \\
\text { station } m \text {. }\end{array}$ \\
\hline$t_{i m k}^{\operatorname{Comp} p}$ & $\begin{array}{l}\text { Completion time for product } i \text { in position } k \text { in } \\
\text { station } m \text {. }\end{array}$ \\
\hline & $\begin{cases}1, & \text { if product i produced in station } m, \text { in position } k . \\
0, & \text { else }\end{cases}$ \\
\hline $\mathrm{km}$ & $\left\{\begin{array}{c}1, \text { if product i produced at } k^{\text {th }} \text { position and product i produced } \\
\text { at }(k+1)^{\text {th }} \text { position }\end{array}\right.$ \\
\hline
\end{tabular}

\subsubsection{Objective functions}

$$
\operatorname{Min} f_{1}=\sum_{i \in I} \sum_{m \in M} \sum_{k \in K} t_{i m k}^{\operatorname{Comp} p}
$$




$$
\begin{aligned}
& =\sum_{i \in I} \sum_{m \in M} c_{i m}^{\text {Pro }} \sum_{i \in I} \sum_{m \in M} \sum_{k \in K}^{\text {Min } f_{2}} \theta_{i k m}+\sum_{i \in I}\left(c_{i}^{\text {Lost }} H_{i}\right) \\
& +\sum_{i \in I} \sum_{i=I}^{m \in M} \sum_{m \in M} c_{i i^{\prime} m}^{\text {Setup }} \sum_{i \in I}^{m} \sum_{i^{\prime} \in I} \sum_{m \in M} \sum_{k \in K} W_{i i^{\prime} k m} \\
& +\sum_{i \in I}\left(c_{i}^{I n v} \operatorname{Inv} v_{i}\right) \\
& \sum_{i \in I} \theta_{i k m}=1, \quad \forall k \in K, m \in M \\
& t_{i m(k+1)}^{\text {Start }} \geq t_{i m k}^{\text {Comp }}, \quad \forall i \in I, k \in K, m \in M \\
& t_{i m k}^{\text {Comp }}=t_{i m k}^{\text {Start }}+t_{i m}^{\text {Pro }} \theta_{i k m}+\sum_{i^{\prime} \in I}\left(t_{i i^{\prime} m}^{\text {Setup }} W_{i i^{\prime} k m}\right) \text {, } \\
& \forall i, \in I, k \in K, m \in M \\
& \sum_{k \in K} \sum_{m \in M} \theta_{i k m}+H_{i}-I_{n} v_{i}=d_{i}, \quad \forall i \in I \\
& \sum_{i \in I} \sum_{k \in K} \theta_{i k m} \sum_{i \in I} t_{i m}^{\text {Pro }} \leq \operatorname{Cap}_{m} W D, \quad \forall m \in M \\
& W_{i i{ }^{\prime} \mathrm{km}} \geq \theta_{i k m}+\theta_{i^{\prime}(k+1) m}-1, \\
& \forall i, i^{\prime} \in I, k \in K, m \in M \\
& t_{\text {imk }}^{\text {Comp }} \leq D_{\text {Due }}, \quad \forall i \in I, m \in M, k \in K \\
& H_{i} \geq 0, \quad \forall i \in I \\
& I n v_{i} \geq 0, \quad \forall i \in I \\
& t_{i m k}^{\text {Comp }} \geq 0, \quad \forall i \in I, m \in M, k \in K \\
& t_{\text {imk }}^{\text {Start }} \geq 0, \quad \forall i \in I, m \in M, k \in K \\
& \theta_{i k m} \in\{0 \mid 1\}, \quad \forall i \in I, m \in M, k \in K \\
& W_{i i^{\prime} k m} \in\{0 \mid 1\}, \quad \forall i, i^{\prime} \in I, m \in M, k \in K
\end{aligned}
$$

Equation (1) aims to minimize total completion time of products and indicates one of the objective functions of this problem. Equation (2) shows the second objective function to minimize total cost. The parts of this equation indicates production cost, lost sale cost, setup cost and inventory cost, respectively. Equation (3) ensures that there can be only one product in every position. Equation (4) demonstrates that after the completion of job $i$ in $k^{\text {th }}$ order in station $m$, another job $i$ can start in $(k+1)^{\text {th }}$ order in station $m$. Equation (5) demonstrates that the completion time of any product $i$ is equal to summation of its production time and starting time, also considering setup times between two products. Equation (6) shows that the total weekly demand and backordered quantities of product $i$ should be satisfied by total production of product $i$ in all sequences and at all stations, and/or from inventory level of product $i$. If summation of all processed products in all machines and all orders is considered, first term in Equation (6) indicates total number of processed products in a unit of "pieces" and it can be considered that cumulative value of the first term will be equal to total number of processed units due to binary condition of $\theta_{i k m}$. Equation (7) shows that the total production time of products should not exceed total weekly capacity of production. Equation (8) ensures that if product $i$, which will be produced after product $i$, is produced in $(k+1)^{\text {th }}$ position, product $i$ should be produced in $k^{\text {th }}$ position. Equation (9) illustrates that completion time of any product $i$ cannot exceed its due date. Therefore, all required demand will be produced and delivered on time. Equation (10)-(11) show that total number of backorders and inventory level for product $i$ cannot take any negative values. The value of start time and completion time of any product $i$ also cannot be negative according to Equation (12) and (13). Finally, Equation (14) and (15) show the conditions for binary variables of model.

\section{Solution methodology}

In real-life cases, consideration of a single objective function will not be realistic and more than one objective function should be considered to realize the real-life conditions. Therefore, proposed model has two important objective functions considering total processing cost and make-span. There are many methodologies proposed to get Pareto solution sets for illustrative cases. Weighted sum method and epsilon method are most frequently used methods to get nondominated solution sets for bi-objective problems. In the weighted sum method, model integrates a set of objective functions into a single objective function by multiplying each objective function with pre-determined weights. The weights of objective functions are chosen based on importance of the objectives. However, it is difficult to set the weight vectors to obtain a Pareto frontier in the objective space. In this study, augmented epsilon constraint method proposed by Mavrotas [19], AUGMECON (Augmented $\epsilon$-constraint method), is used. The main benefit of this model is to find alternative solution set that can improve at least one objective function by deteriorating another objective function in every iteration. The non-dominated solution set for bi-objective problem can be collected by spending less computational effort while stabilizing the parameters [20].

In manufacturing industry, the cost objective has more importance than the other objectives and companies are more sensitive about this parameter due to high competitive conditions. Therefore, we took cost function $\left(f_{1}\right)$ as a primal objective function and total make-span $\left(f_{2}\right)$ is taken as a secondary objective function. Then, it is inserted as a constraint in the $\epsilon$-constraint method. In this solution algorithm, multiplication of slack variable $\left(X_{S}\right)$ with some small constant value (such as this value is $10^{-5}$ in this study) is subtracted from $f_{1}$ to deteriorate the objection function. However, same slack variable is included into $f_{2}$ at the same time and summation of second objective function with this slack variable should be equal to the upper bound of total makespan function.

$$
\operatorname{Min}\left\{f_{1}-\epsilon X_{s}\right\}
$$

Subject to

$$
f_{2}+X_{s}=f_{2}^{u p p e r}
$$

Equation (3)-Equation (15)

\section{Computational experiments}

This study was applied to a manufacturing company of construction machines and equipment that has flexible jobshop manufacturing system. Detailed information about 
explanation of parameters, constant data used in the model are shared in this section.

Firstly, seven different types of products are considered in our case study and coded as T197, T222, T235, T245, T246, T257, T258. In addition, three parallel production lines are given as S-a, S-b, S-c. Production times of different products at any station are calculated with time studies listed in Table 1 in a unit of hours.

Table 1: Production times of any product at any station.

\begin{tabular}{cccc}
\hline$[\mathrm{h}]$ & S-a & S-b & S-c \\
\hline T197 & 6.9 & 8.3 & 7.1 \\
T222 & 9 & 8.2 & 9.4 \\
T235 & 10 & 9.5 & 9.4 \\
T245 & 7.9 & 10.6 & 14 \\
T246 & 17.3 & 15.8 & 16.3 \\
T257 & 12.9 & 13 & 13.1 \\
T258 & 7.7 & 14.2 & 12.1 \\
\hline
\end{tabular}

Secondly, demand for products is taken as a real data of company as shown in Table 2.

Table 2: Weekly demands for each product type [pieces].

\begin{tabular}{ccccccc}
\hline T197 & T222 & T235 & T245 & T246 & T257 & T258 \\
\hline 3 & 5 & 4 & 5 & 4 & 2 & 3 \\
\hline
\end{tabular}

Daily capacity of each station is also given, and it was calculated approximately 17.67 hours for every station because the working hours of the company begins at 8:00 $\mathrm{AM}$ and ends at 6:00 PM and it is assumed that two workers works on every station. Moreover, each worker has a lunch break of $40 \mathrm{~min}$. and tea breaks lasting $15 \mathrm{~min}$.

The next parameter is for working days, and the production period of company lasts for 6 days in a week (from Monday to Saturday).

Setup times for preparation of new product type and changing equipment from product $i$ to product $i^{\prime}$ in station $\mathrm{S}$-a is assumed as in Table 3 in a unit of minutes.

Table 3: The Setup durations between product groups at production line S-a.

\begin{tabular}{cccccccc}
\hline [min] & T197 & T222 & T235 & T245 & T246 & T257 & T258 \\
\hline T197 & - & 125 & 150 & 135 & 150 & 25 & 56 \\
T222 & & - & 115 & 80 & 125 & 84 & 70 \\
T235 & & & - & 85 & 80 & 130 & 150 \\
T245 & & & & - & 95 & 104 & 112 \\
T246 & & & & & - & 95 & 137 \\
T257 & & & & & & - & 145 \\
T258 & & & & & & - \\
\hline
\end{tabular}

Table 4 shows processing costs of different product types at different stations. There can be cost differences for same product on different production lines due to the special tool requirements. For example, product T197 and T257 are produced generally in Station A (S-a), therefore, their processing costs are lower than the others.

Table 4: Processing costs of different products at each station.

\begin{tabular}{cccc}
\hline$[€]$ & S-a & S-b & S-c \\
\hline T197 & 85 & 150 & 120 \\
T222 & 150 & 98 & 130 \\
T235 & 160 & 160 & 67 \\
T245 & 170 & 150 & 190 \\
T246 & 180 & 140 & 180 \\
T257 & 85 & 130 & 170 \\
T258 & 190 & 98 & 160 \\
\hline
\end{tabular}

The cost for lost sales defined for all products and machines is assumed as a big number in order to reduce number of backorders. So, it is assumed to be $€ 50,000$. The reason for such a high cost is that sale price of the finished products is approximately €50,000 and any delay in the fulfillment of the tanks will directly affect the sales process.

The setup costs of products in Station A are given in Table 5. Other values are given as appendix.

Table 5: An Example for Setup Costs in Station A (S-a).

\begin{tabular}{cccccccc}
\hline$[€]$ & T197 & T222 & T235 & T245 & T246 & T257 & T258 \\
\hline T197 & - & 1,050 & 955 & 1,015 & 1,020 & 1,055 & 1,035 \\
T222 & & - & 1,025 & 1,255 & 855 & 1,105 & 880 \\
T235 & & & - & 1,015 & 1,010 & 1,000 & 875 \\
T245 & & & & - & 965 & 980 & 1,135 \\
T246 & & & & & - & 975 & 1,045 \\
T257 & & & & & & - & 1,050 \\
T258 & & & & & & & - \\
\hline
\end{tabular}

The last parameter is related with due dates of products that are given in Table 6 and they are written in a unit of hours. It is assumed that period for due date starts from 1 that is equal to beginning of the week (Monday - 8:00 AM) and goes to 48 that is the last working hour of the week (Saturday - 05:00 PM).

Table 6: Due dates of products [in unit of hours].

\begin{tabular}{ccccccc}
\hline T197 & T222 & T235 & T245 & T246 & T257 & T258 \\
\hline 8 & 16 & 24 & 32 & 40 & 40 & 48 \\
\hline
\end{tabular}

\section{Results}

In this section, we examined the details of developed mathematical model and obtained Pareto solutions by using real-life data for job-shop scheduling problem. Moreover, results are shared with relevant stakeholders and comparison analysis (before-after analysis) is made to indicate the efficiency of proposed model. Developed mathematical model is executed in GAMS language compiler by using IBM ILOG CPLEX 12.1 solver to obtain feasible solutions. Proposed model is executed on a computer with Intel Core I5 $2520 \mathrm{M} \mathrm{CPU}$ with $2.50 \mathrm{GHz}$ dual core processor, and with $4.00 \mathrm{~GB}$ of RAM. An optimality gap of $1 \%$ is set for the solutions.

During the solution steps, different number of job orders and production lines are used under three different scenarios. Illustrative cases are designed based on real-life data in order to highlight the difference between current scheduling plans and proposed schedules for different cases. Three-week scenarios of company are chosen randomly and applied into the model. The main aim of this choice process is to handle as much as possibly different product groups. Pareto results for total make-span and total processing cost are shared and sensitivity analysis of three cases are given in terms of computational performance unit times. The main difference between these cases is the number of orders processed in the production lines as given in Table 7. Afterwards, results of the model are shared according to different cases.

Table 7. Details of illustrative case scenarios.

\begin{tabular}{|c|c|c|}
\hline Cases & $\begin{array}{l}\text { \# of orders to } \\
\text { be processed }\end{array}$ & Details \\
\hline $\begin{array}{l}\text { Scenario } \\
\text { \#1 }\end{array}$ & 27 & $\begin{array}{c}6 \mathrm{~T} 235+6 \mathrm{~T} 245+5 \mathrm{~T} 246+4 \\
\mathrm{~T} 197+4 \mathrm{~T} 222+2 \mathrm{~T} 257\end{array}$ \\
\hline $\begin{array}{l}\text { Scenario } \\
\quad \# 2\end{array}$ & 28 & $\begin{array}{c}6 \mathrm{~T} 235+6 \mathrm{~T} 245+5 \mathrm{~T} 246+4 \\
\mathrm{~T} 197+4 \mathrm{~T} 222+2 \mathrm{~T} 257+1 \\
\text { Accessorize }\end{array}$ \\
\hline $\begin{array}{l}\text { Scenario } \\
\quad \# 3\end{array}$ & 34 & $\begin{array}{c}6 \mathrm{~T} 235+6 \mathrm{~T} 245+5 \mathrm{~T} 246+4 \\
\mathrm{~T} 197+4 \mathrm{~T} 222+2 \mathrm{~T} 257+2 \mathrm{~T} 279 \\
+3 \mathrm{~T} 280+2 \mathrm{~T} 281\end{array}$ \\
\hline
\end{tabular}




\subsection{Scenario \#1}

First, the upper and lower bounds of the objective functions are found by using $\epsilon$-constraint method to minimize total makespan and processing cost separately as given in Table 8 . Based on the results of model, all 27 products ( 6 different product groups) are produced under the given constraints. However, it is observed that total processing cost should increase $9.9 \%$ to reduce make-span $27.4 \%$.

Table 8: Results summary for scenario 1.

\begin{tabular}{cccc}
\hline $\begin{array}{c}\text { Objective } \\
\text { Function }\end{array}$ & $\begin{array}{c}\text { Production } \\
\text { Cost [k€] }\end{array}$ & $\begin{array}{c}\text { Make-Span } \\
{[\mathrm{h}]}\end{array}$ & CPU [sec] \\
\hline$f_{1}$ & 2,035 & 110.8 & 0.015 \\
$f_{2}$ & 2,260 & 80.4 & 0.078 \\
\hline
\end{tabular}

Model is tested by using $\epsilon$-constraint method and Pareto solution sets are obtained by considering minimization of make-span and processing costs as given in Figure 1.

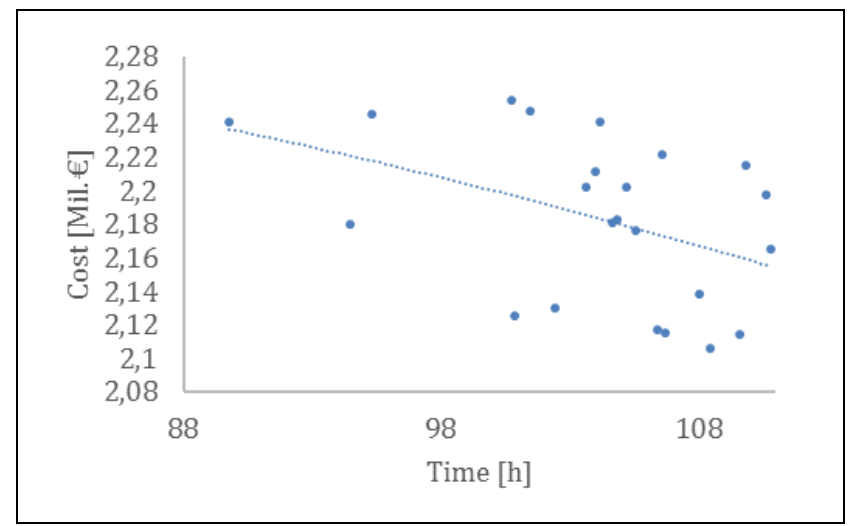

Figure 1: Pareto solutions for scenario 1 (Time vs Cost).

Figures 1 shows Pareto solution set of proposed problem in terms of total make-span and processing cost. Each point in this range gives a feasible solution and decision maker can choose any of these points. Solution sets are clustered mainly in a range of [103-105] h and [2.17-2.22] mil. €.

\subsection{Scenario \#2}

The results of second scenario are given in Table 9. Based on the results of model, all 28 products ( 7 different types) are produced under given constraints. However, it is observed that total production cost should increase $4.9 \%$ to reduce makespan $26.3 \%$.

Table 9: Results summary for scenario 2.

\begin{tabular}{cccc}
\hline $\begin{array}{c}\text { Objective } \\
\text { Function }\end{array}$ & $\begin{array}{c}\text { Production } \\
\text { Cost }[\mathrm{k} €]\end{array}$ & $\begin{array}{c}\text { Make-Span } \\
{[\mathrm{h}]}\end{array}$ & CPU [sec] \\
\hline$f_{1}$ & 102,290 & 105.7 & 0.032 \\
$f_{2}$ & 107,317 & 77.9 & 0.015 \\
\hline
\end{tabular}

Figure 2 shows Pareto threshold for scenario \#2 and any point in this figure indicates different feasible solution for decision makers. However, if any stakeholders would like to save some time in make-span duration, they should spend much more money for production operations. For example, red triangles in Figure 2 indicate positions of two possible solution sets. If someone would like reduce their make-span from $84.3 \mathrm{~h}$ to 78.8 $\mathrm{h}$, additional 2.6 mil. $€$ should be spent for production activities.

\subsection{Scenario \#3}

In Scenario 3, system is run for nine different products and result data is tabulated in Table 10 . Total make-span increased approximately $18 \%$ and total cost decreased approximately $1.3 \%$ according to iterations.

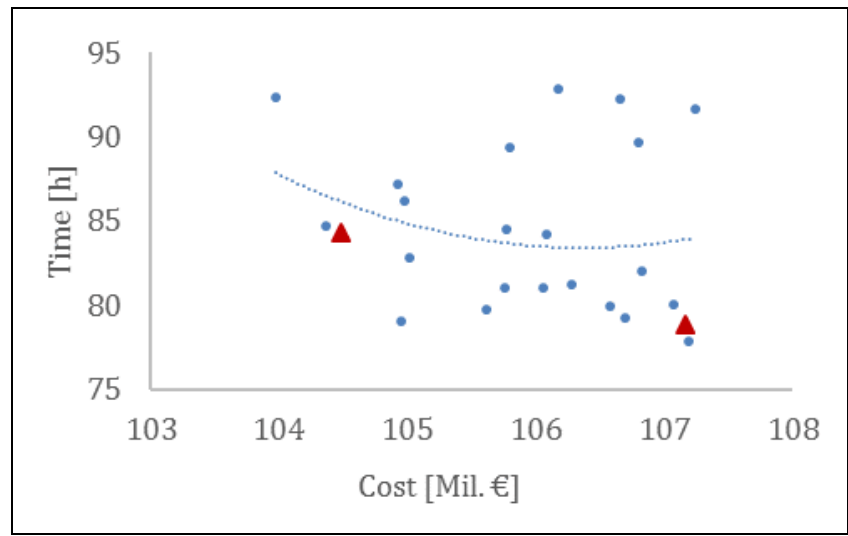

Figure 2: Pareto solution set for scenario 2.

Table 10: Results summary for scenario 3.

\begin{tabular}{cccc}
\hline $\begin{array}{c}\text { Objective } \\
\text { Function }\end{array}$ & $\begin{array}{c}\text { Production } \\
\text { Cost }[\mathrm{k} €]\end{array}$ & $\begin{array}{c}\text { Make-Span } \\
{[\mathrm{h}]}\end{array}$ & CPU [sec] \\
\hline$f_{1}$ & 351,581 & 96.2 & 0.032 \\
$f_{2}$ & 356,066 & 78.8 & 0.047 \\
\hline
\end{tabular}

In Figure 3, red triangles show that if someone would like to save 1.7 mil $€$ in production costs, make-span of the system will increase from $78.8 \mathrm{~h}$ to $84.5 \mathrm{~h}$.

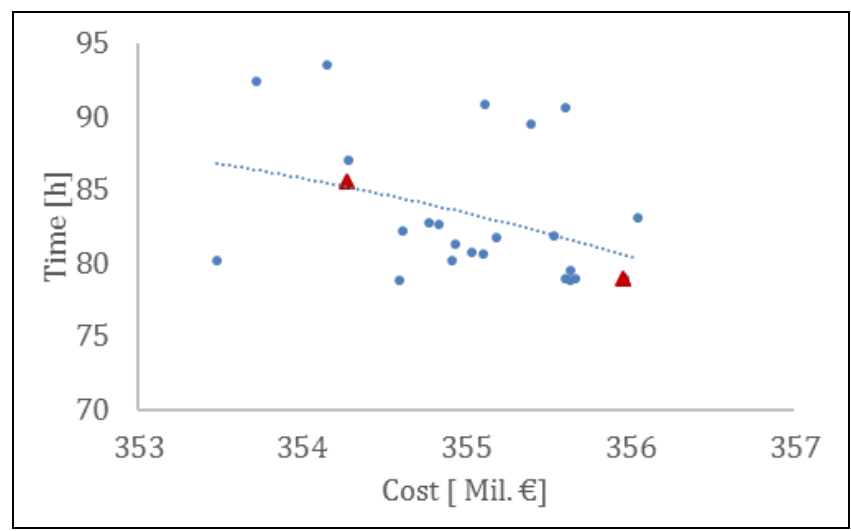

Figure 3: Pareto Solution set for scenario 3.

According to results of three different cases, comparison of CPU times in terms of iterations are given in Figure 4.

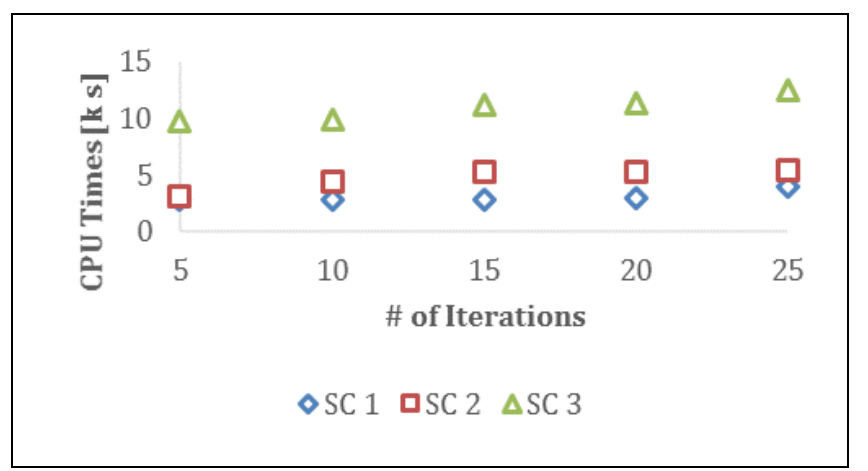

Figure 4: CPU times comparison for different cases. 
As given in Figure 4, when the number of orders are increased (from Scenario 1 to Scenario 3), total computational effort is also increased in a range of $35.4 \%-214.9 \%$. For example, if number of orders is increased $3.7 \%$, relevant CPU effort is increased around $35.4 \%$. However, if number of orders is increased $25.9 \%$, CPU time is increased around $214.9 \%$.

After Pareto solution sets are obtained by using $\epsilon$-constraint method, results of proposed model are compared with the current scheduling of the company. Moreover, demand samples are taken for three stations, and tardy jobs, total costs, total waiting times, idle times are given in outputs of scheduling.

Gantt chart of the current production plan of the company as given in Figure 5. According to real demand data, total number of demands for one-week period is equal to 34 and company planned to produce 26 of them in one week but as it is seen in Figure 5, they could only finish 15 out of 26 tanks. This situation ended up having tardy jobs. They could only complete all demands of three type of tanks that are T246, T197 and T280 in a given week. This result is significantly different from their production plans. They could only manage to produce three T235 and all demand requirements of T246, T197 and T280; however, they could not start production of T245 and T222, also they could not finish the production of T281. There are two main problems behind this backordering situation. One of them is the reduction in the work force capacity of stations. They usually work with two workers per each station, but in this case, they used only one worker at Station b and Station c due to the unavailability of the workers in the industry. Second one is the lack of production planning tool in the company.
Figure 6 illustrates proposed weekly scheduling plan according to the results of GAMS under the capacity of a worker for Stations b and c; two workers for Station A. In this scenario, although there are still tardy jobs, 18 products can be produced in total. If the result of this scenario is compared with the current situation of the company, proposed solution includes production of more products types. This means that there are some productions for T222, T279, T281. In addition, two more products are produced compared to the current situation. There is total seven-hours idle time in the system. Figure 7 demonstrates second proposed scheduling done by GAMS under the capacity of two workers for all stations. In this case, total number of tank production is equal to 27 out of 34 and this means that most of the tanks can be produced on time and there is an idle time of an hour in Station b (S-b). This scenario is close to the more realistic cases because the company originally designed the stations in a way that two workers can work at the same time in one station. Thanks to this scheduling, number of tardy jobs are reduced dramatically as the efficiency is increased. As a result, when the first Gantt chart and the second Gantt chart are compared, it can be clearly seen that total amount of production is increased by 12 and the number of tardy jobs is also decreased in the second proposed scheduling where all stations work mostly at their full capacity.

Figure 8 shows the production sequence of different products during a week period in different stations for Scenario 3. For example, if Machine-C is observed, there is a production of four units of T235 after the production of T279. This means that production plan for Machine C is T279-T235-T235-T235-T235T281-T279-T235 during a week-period.

\begin{tabular}{|c|c|c|c|c|c|c|c|c|c|c|c|c|c|c|c|c|c|c|c|c|c|c|c|c|c|c|c|c|c|c|c|c|c|c|c|c|c|c|c|c|c|c|c|c|}
\hline \multirow{2}{*}{$\begin{array}{l}\text { Days } \\
\text { Hours }\end{array}$} & \multicolumn{8}{|c|}{ MONDAY } & \multicolumn{8}{|c|}{ TUESDAY } & \multicolumn{6}{|c|}{ WEDNESDAY } & \multicolumn{8}{|c|}{ THURSDAY } & \multicolumn{8}{|c|}{ FRIDAY } & \multicolumn{6}{|c|}{ SATURDAY } \\
\hline & 1 & 2 & 3 & 4 & 5 & 6 & 7 & 8 & 1 & 2 & 3 & 4 & 5 & 6 & $\begin{array}{ll}78 \\
\end{array}$ & $\begin{array}{ll}8 & 1 \\
\end{array}$ & 2 & 3 & 4 & 5 & 67 & 7 & $8 \quad 1$ & 12 & 3 & 4 & 5 & 6 & 7 & 8 & 1 & 2 & 3 & 4 & 5 & 6 & 7 & 8 & 1 & 2 & $\begin{array}{|ll|}3 & 4 \\
\end{array}$ & 5 & 67 & 788 \\
\hline Machine A & & & & & & & & & & & & & & & T246( & $5(4 \mathrm{UN}$ & ITSS) & & & & & & & & & & & & & & & & & & & & & & $\mathrm{T} 235 \mathrm{C}$ & (3 UNI & ITSS) & & & \\
\hline Machine B & & & & & & & & & & & & & & & & & & & & & $197(6$ & UNI & & & & & & & & & & & & & & & & & & & & & & \\
\hline Machine $\mathrm{C}$ & & & & & & & & & & & & & & & & $\mathrm{T} 280 \mathrm{C}$ & $2 \mathrm{UNI}$ & & & & & & & & & & & & & & & & & & & & & & & T281 ( & (1 UNIT) & & & \\
\hline
\end{tabular}

Figure 5: Current scheduling plan done by the company.

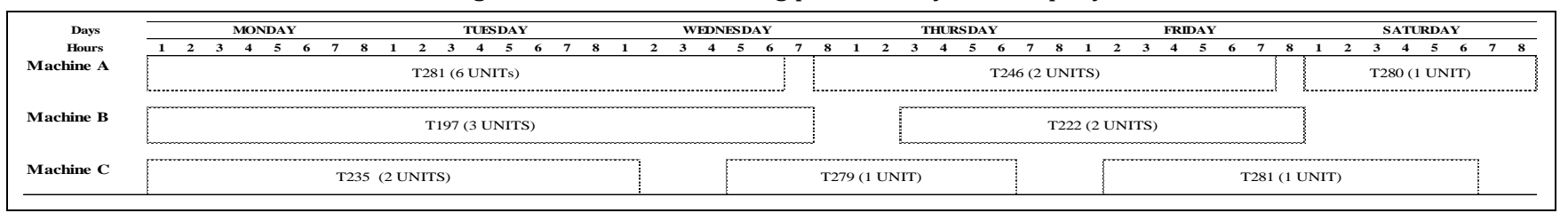

Figure 6: Proposed scheduling under the capacity of one worker for station B and C.

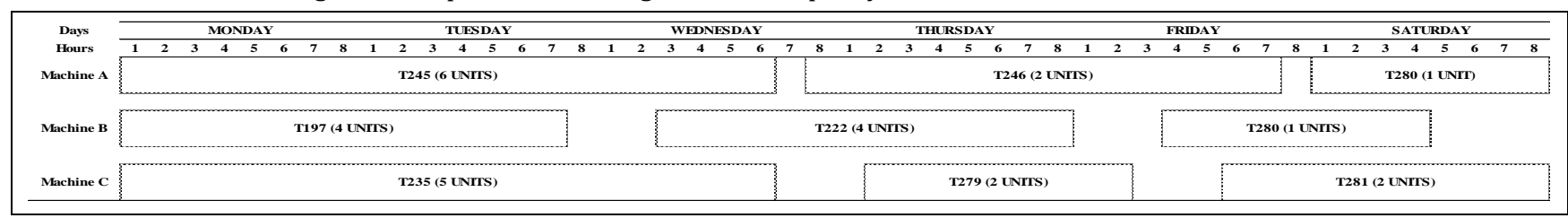

Figure 7: Proposed scheduling under the capacity of two workers for Station A, B and C.

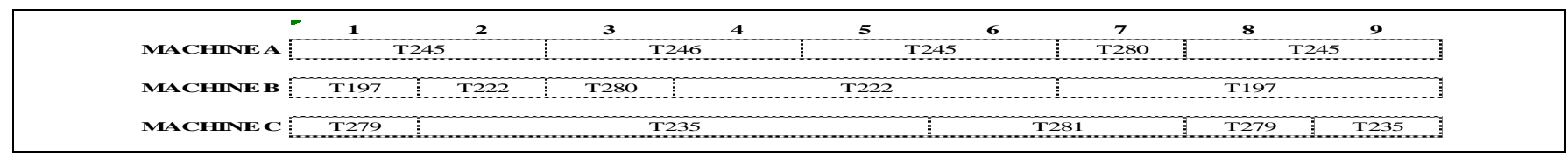

Figure 8: Job order sequence of products for a week period. 


\section{Conclusion}

One of the main reasons behind unsatisfied customer demands or backorders is mostly due to inappropriate scheduling plans. Because of this situation, companies may produce more or less than their needs and this situation causes lost-sales or inventory cost. In this study, a mixed-integer linear mathematical model is designed and developed to figure out inappropriate scheduling problems. Minimizing total make-span and total processing cost are considered as a biobjective problem for real-life cases. AUGMECON method is used as a solution methodology and afterwards, it is applied to real-life data of company producing heavy machines and equipment. Developed mixed-integer linear mathematical model is applied for three main scenarios and Pareto solution sets are obtained for these scenarios. When outcomes of the model and current scheduling of the company are compared, it is seen that production efficiency of the company is increased around $16.6 \%$ in terms of processing cost. In addition, there is a significant increase in the number of production quantities as well as increase in the efficiency of the system (considered decrease in idle times). The proposed linear model also fastens the decision process and fulfill Pareto solution sets for stakeholders. The decision makers can get alternative plans in seconds because average CPU time is around 12 seconds for most complicated scenario for the company.

\section{References}

[1] Kalite Derneği (TMME). “2016 Türkiye Müşteri Memnuniyeti Endeksi". http://www.kalder.org/tmme (11/02/2018).

[2] Johnson SM. "Optimal two and three stage production schedules with setup times included". Naval Research Logistics Quarterly, 1(1), 61-8, 1954.

[3] Van Wassenhove LN, Baker KR. "A bi-criterion approach to time/cost trade-offs in sequencing". European Journal of Operational Research, 11(1), 48-54, 1982.

[4] Brucker P, Schlie R. "Job-shop scheduling with multi-purpose machines". Computing, 45(4), 369-375, 1990.

[5] Yazdani M, Gholami M, Zandieh M, Mousakhani M. "A simulated annealing algorithm for flexible job-shop scheduling problem". Journal of applied sciences, 9(4), 662-670, 2009.

[6] Kacem I, Hammadi S, Borne P. "Approach by localization and multi-objective evolutionary optimization for flexible job-shop scheduling problems". IEEE Transactions on Systems, Man and Cybernetics, 32(1), 1-13, 2002.

[7] Paulli J. "A hierarchical approach for FMS scheduling problem". European Journal of Operational Research, 86, 32-42, 1995.

[8] Watanabe M, Ida K, Gen M. "A genetic algorithm with modified crossover operator and search area adaptation for the job-shop scheduling problem". Computers \& Industrial Engineering, 48(4), 743-752, 2005.
[9] Fattahi P, Saidi M, Jolai F. "Mathematical modeling and heuristic approaches to flexible job shop scheduling problems". Journal of Intelligent Manufacturing, 18, 331-342, 2007.

[10] Gao J, Gen M, Sun L, Zhao X. "A Hybrid of genetic algorithm and bottleneck shifting for multi-objective flexible job shop scheduling problems". Computers \& Industrial Engineering, 53(1), 149-162, 2007.

[11] Chiang TC, Lin HJ. "A simple and effective evolutionary algorithm for multi-objective flexible job shop scheduling". International Journal of Production Economics, 141 (1), 87-98, 2012.

[12] Li J, Pan Q, Xie S. "An effective shuffled frog-leaping algorithm for multi-objective flexible job shop scheduling problems". Applied Mathematics and Computation, 218, 9353-9371, 2012.

[13] Abdeljaouad MA, Bahroun Z, Omrane A, Fondrevelle J. "Job-shop production scheduling with reverse flows". European Journal of Operational Research, 244(1), 117-128, 2015.

[14] Gedik R, Rainwater C, Nachtmann H, Pohl EA. "Analysis of a parallel machine scheduling problem with sequence dependent setup times and job availability intervals". European Journal of Operational Research, 251(2), 345-694, 2016.

[15] Özgüven C, Yavuz Y, Özbakır L. "Mixed integer goal programming models for the flexible job-shop scheduling problems with separable and non-separable sequence dependent setup times". Applied Mathematical Modelling, 36(2), 505-862, 2012.

[16] Xue G, Offodile OF, Zhou H, Troutt MD. "Integrated production planning with sequence-dependent family setup times". International Journal of Production Economics, 131(2), 674-681, 2011.

[17] Shen L, Dauzère-Pérèsb S, Neufeldd JS. "Solving the flexible job shop scheduling problem with sequencedependent setup times". European Journal of Operational Research, 265, 399-794, 2017.

[18] Gao KZ, Suganthan PN, Pan QK, Chua TJ, Cai TX, Chong CS. "Discrete harmony search algorithm for flexible job shop scheduling problem with multiple objectives". Journal of Intelligent Manufacturing, 27(2), 1-12, 2014.

[19] Mavrotas G. "Effective implementation of the e-constraint method in multi-objective mathematical programming problems". Applied Mathematics and Computation, 213, 455-465, 2009.

[20] Resat HG, Turkay M. “A discrete-continuous optimization approach for the design and operation of synchromodal transportation networks". Computer and Industrial Engineering, 130, 512-525, 2019. 